\title{
Amiodarone Increases the Accumulation of DEA in a Human Alveolar Epithelium-Derived Cell Line
}

\author{
Satoru Seki, Shirou Itagaki, Masaki Kobayashi, Takeshi Hirano, and Ken Iseki* \\ Laboratory of Clinical Pharmaceutics \& Therapeutics, Division of Pharmasciences, Faculty of Pharmaceutical Sciences, \\ Hokkaido University; Kita-12-jo, Nishi-6-chome, Kita-ku, Sapporo 060-0812, Japan. \\ Received April 3, 2008; accepted April 24, 2008; published online May 1, 2008
}

\begin{abstract}
Amiodarone (AMD)-induced pulmonary toxicity (AIPT) is the most life-threatening side-effect of AMD treatment. $N$-Monodesethylamiodarone (DEA), an active metabolite of AMD, also exhibits cytotoxicity and tends to accumulate in the lung more intensively than AMD. In this study, we characterized the mechanism of DEA accumulation using A549 cells as a model of the alveolar epithelium. Typical ATP-depletion compounds caused an approximately $30 \%$ increase in the accumulation of DEA in A549 cells, although these effects were less than those in Caco-2 cells. Triiodothyronine $\left(T_{3}\right)$, which exhibited an inhibitory effect on DEA efflux in Caco-2 cells, did not affect the accumulation of DEA in A549 cells. On the other hand, $100 \mu \mathrm{M}$ AMD caused an approximately $200 \%$ increase in DEA content in A549 cells, although AMD accumulation was not affected by $100 \mu \mathrm{M}$ DEA. Since the reducing effect of AMD on cellular ATP levels and that of FCCP were similar, the mechanism by which DEA accumulation is increased by AMD might be different from the ATP-dependent DEA efflux mechanism. The decrease in cell viability by DEA in the presence of $A M D$ (IC ${ }_{50}$ value of DEA for A549 cell viability: $25.4 \pm 2.4 \mu \mathrm{M})$ was more pronounced than that by DEA alone $\left(\mathrm{IC}_{50}\right.$ value: $\left.11.5 \pm 3.0 \mu \mathrm{M}\right)$. This further DEA accumulation by AMD might be a factor responsible for the greater accumulation of DEA than that of AMD in the lung in long-term AMD-treated patients.
\end{abstract}

Key words amiodarone; $N$-monodesethylamiodarone; amiodarone-induced pulmonary toxicity

Amiodarone (AMD) is a highly effective drug for the treatment of cardiac dysrhythmias. ${ }^{1)}$ Clinical evidence suggests that this drug has a role in reducing the relative risk for arrhythmic or sudden death and overall mortality in survivors of myocardial infarction and in heart failure patients. ${ }^{2)}$ Among the various antiarrhythmic agents, AMD has electrophysiological effects that most closely approximate those of an ideal antiarrhythmic agent. ${ }^{3)}$ Although AMD is used widely, ${ }^{4)}$ AMD-induced pulmonary toxicity (AIPT) limits the clinical use of AMD. ${ }^{5-7)}$ AIPT has been clinically diagnosed in 5 to $10 \%$ of patients receiving high doses of AMD and in $1.6 \%$ of patients receiving AMD at a dose of $400 \mathrm{mg} / \mathrm{d}$ or less. ${ }^{8)}$ Because of its high potential for mortality, AIPT is the adverse event of greatest concern for patients receiving AMD therapy.

In humans, AMD is metabolized to $N$-monodesethylamiodarone (DEA), an active metabolite of AMD, by P450 (CYP) 3A. ${ }^{9-12)}$ The blood concentration of DEA has been shown to be comparable with that of AMD. ${ }^{13-15)}$ The mechanisms of AMD- or DEA-induced cytotoxicity, including altered inflammatory mediator release, ${ }^{16}$ phosopholipidosis promotion, ${ }^{17)}$ mitochondrial dysfunction ${ }^{18)}$ and free radical production, ${ }^{19)}$ have been extensively studied. On the other hand, the tendencies of AMD and DEA to accumulate in the lung ${ }^{20)}$ are also considered factors responsible for the initiation of AIPT, and it is possible that some mechanisms contribute to the accumulation of both compounds. The accumulation of DEA in the lung is greater than that of AMD. Adams et al. reported that the DEA concentration in lung tissue of long-term AMD-treated patients was approximately 5-hold higher than that of AMD. ${ }^{21)}$ Furthermore, DEA is more cytotoxic than AMD in lung cells ${ }^{16)}$ and in non-pulmonary cell types. ${ }^{22)}$ Thus, it is important to elucidate the transport mechanisms of DEA in the lung. However, the transport mechanisms of DEA as well as those of AMD have not been investigated in detail. It has been reported that DEA and AMD inhibited the transport of digoxin by human MDR1 cDNA-transfected $\mathrm{LLC} \mathrm{PK}_{1}$ cells ${ }^{23)}$ but it is unclear whether P-glycoprotein (Pgp) recognizes DEA and AMD as a substrate.

Previously, we demonstrated that DEA accumulation was increased under an ATP-depleted condition in Caco-2 cells and that triiodothyronine $\left(\mathrm{T}_{3}\right)$ also increased the accumulation of DEA by Caco-2 cells. ${ }^{24)}$ In this study, to clarify the mechanism of high accumulation of DEA in the lung, we investigated the mechanism of AMD or DEA accumulation in A549 cells, a human alveolar epithelium-derived cell line.

\section{MATERIALS AND METHODS}

Chemicals AMD and DEA were kindly supplied by Taisho Pharmaceutical (Tokyo, Japan). All other reagents were of the highest grade available and used without further purification. AMD and DEA were dissolved in methanol (1\% $\mathrm{w} / \mathrm{v}$ final concentration) due to their hydrophobic properties and poor solubility in water.

Cell Culture A549 cells obtained from American Type Culture Collection (Rockville, MD, U.S.A.) were maintained in plastic culture flasks (Falcon, Becton Dickinson and Co., Lincoln Park, NJ, U.S.A.). These stock cells were subcultivated before reaching confluence. The medium consisted of Dulbecco's Modified Eagle's Medium (Sigma, St. Louis, MO, U.S.A.) supplemented with $10 \%$ fetal bovine serum (ICN Biomedicals, Inc., Aurora, OH, U.S.A.) and $100 \mathrm{IU} / \mathrm{ml}$ penicillin $-100 \mu \mathrm{g} / \mathrm{ml}$ streptomycin (Sigma). The monolayer cultures were grown in an atmosphere of $5 \% \mathrm{CO}_{2}-95 \%$ air at $37^{\circ} \mathrm{C}$. The cells were given fresh growth medium every $2 \mathrm{~d}$. When the A549 cells had reached confluence, they were harvested with $0.25 \mathrm{~mm}$ trypsin and $0.2 \%$ EDTA $(0.5-1 \mathrm{~min}$ at $37^{\circ} \mathrm{C}$ ), resuspended, and seeded into a new flask. For the uptake study, A549 cells were seeded at a cell density of $1 \times 10^{5}$ 
cells/cm ${ }^{2}$ on 24-well plates (Corning Costar Corp., Cambridge, MA, U.S.A.). The cell monolayers were fed a fresh growth medium every $2 \mathrm{~d}$ and were used at 4 to $6 \mathrm{~d}$ for uptake experiments.

Uptake Study in A549 Cell Monolayers The accumulation of AMD and that of DEA were measured using monolayer cultures grown in 24-well plates. The incubation medium used for the uptake study was HBSS-MES (pH 5.0) buffer $(25 \mathrm{~mm}$ D-glucose, $137 \mathrm{~mm} \mathrm{NaCl}, 5.37 \mathrm{~mm} \mathrm{KCl}$, $0.3 \mathrm{~mm} \mathrm{Na}_{2} \mathrm{HPO}_{4}, 0.44 \mathrm{~mm} \mathrm{KH} \mathrm{PO}_{4}, 1.26 \mathrm{~mm} \mathrm{CaCl}_{2}, 0.8 \mathrm{~mm}$ $\mathrm{MgSO}_{4}$ and $10 \mathrm{~mm}$ MES). After removal of the growth medium, cells were preincubated at $37^{\circ} \mathrm{C}$ for $10 \mathrm{~min}$ with $0.5 \mathrm{ml}$ of HBSS-MES buffer ( $\mathrm{pH} 5.0$ ). After removal of the medium, $0.5 \mathrm{ml}$ of incubation medium containing AMD or DEA was added. The monolayers were incubated for the indicated time at $37^{\circ} \mathrm{C}$. Each cell monolayer was rapidly washed twice with an ice-cold incubation medium at the end of the incubation period. The cells were solubilized with $0.25 \mathrm{ml}$ of $1 \mathrm{~N} \mathrm{NaOH}$ and neutralized with $0.25 \mathrm{ml} 1 \mathrm{~N} \mathrm{HCl}$ After vortexing briefly, a part of the mixture $(100 \mu \mathrm{l})$ was transferred to a fresh tube and $400 \mu \mathrm{l} \mathrm{MeOH}$ was added. After centrifugation of the mixture $(12000 \times \boldsymbol{g}$ for $10 \mathrm{~min})$, the concentration of AMD or that of DEA in the supernatant was measured.

Measurement of ATP Content in A549 Cells Intracellular ATP content was measured using the CellTiter-Glo assay (Promega, Madison, WI, U.S.A.) following the manufacturer's recommendations. A549 cells were plated in 96well plates at a density of 3000 cells per well. Following cell attachment (24h), AMD or FCCP was added for the times indicated. Basal luminescence activity and an ATP standard curve were determined. ATP content was expressed as percent of the control (defined as 100\%).

MTT Assay The 3-(4,5-dimethylthiazol-2-yl)2,5-diphenyl tetrazolium bromide (MTT) assay was performed as described previously ${ }^{25}$ with a certain modification. The MTT assay relies on the production of a colored formazan by the action of mitochondrial enzymes on MTT. For the MTT assay, A549 cells were seeded at a density of $5 \times 10^{3}$ cells/well on 96-well plastic plates. Following cell attachment $(24 \mathrm{~h})$, various concentrations of AMD and DEA were added for the times indicated. At 30-60 min before the end of treatment, $10 \mu \mathrm{l}$ of PBS-containing MTT solution $(0.5 \%)$ was added, and the cells were incubated for a further 30 $60 \mathrm{~min}$. The MTT medium was then replaced with $0.2 \mathrm{ml}$ dimetylsulfoxide, and absorbance was read at $590 \mathrm{~nm}$. Absorbance measured in MTT assays was expressed as percent of the control (defined as $100 \%$ ).

Analytical Procedures AMD or DEA was determined using an HPLC system equipped with a Shimadzu LC liquid chromatograph pump and UV detector. The column was a Mightysil RP-8GP column $(4.6 \times 250 \mathrm{~mm}(5 \mu \mathrm{m})$, Kanto Chemical, Tokyo, Japan). A mobile phase containing $9.5 \mathrm{~mm}$ $\mathrm{H}_{3} \mathrm{PO}_{4}$ : acetonitrile $(1: 1, \mathrm{v} / \mathrm{v})$ was used. Column temperature and flow rate were $40^{\circ} \mathrm{C}$ and $1.0 \mathrm{ml} / \mathrm{min}$, respectively. The wavelength for detection of AMD or DEA was $242 \mathrm{~nm}$. Protein was measured by the method of Lowry et al. with bovine serum albumin as a standard. ${ }^{26}$ )

Statistical significance was evaluated using ANOVA followed by Student's $t$-test, and a value of $p<0.05$ was considered significant. Nonlinear regression analysis was per- formed by using Origin ${ }^{\circledR}$ (version $\left.6.1 \mathrm{~J}\right)$.

\section{RESULTS AND DISCUSSION}

Effects of Various Compounds on the Accumulation of DEA by A549 Cells We investigated the properties of AMD and DEA accumulation in A549 cells. Since the uptake of AMD and that of DEA by A549 cells reached an almost steady state at $30 \mathrm{~min}$ after the start of incubation (data not shown), the accumulation of AMD and that of DEA were characterized by the amount of AMD or DEA remaining in A549 cells for $60 \mathrm{~min}$ in the presence of inhibitors. The amount of AMD remaining in A549 cells for $60 \mathrm{~min}$ and that of DEA were similar $(22.3 \pm 3.4$ and $20.0 \pm 1.6 \mathrm{nmol} / \mathrm{mg}$ protein/60 min, respectively, data not shown). The efflux of AMD was not inhibited by typical ATP-depletion compounds, carbonyl cyanide 4-(trifluoromethoxy) phenylhydrazone (FCCP), carbonyl cyanide $m$-chlorophenylhydrazone (CCCP) and 2,4-dinitrophenol (DNP) (Table 1A). On the other hand, these compounds exhibited inhibitory effects on the efflux of DEA but were less effective compared to the effects observed in our previous study using Caco-2 cells. ${ }^{23)}$ Substrates or inhibitors of ATP-binding cassette (ABC) transporters, such as P-gp (quinidine and digoxin), multidrug reistance-associated proteins (MRPs) (probenecid) and breast cancer resistance protein (BCRP) (mitoxantrone and prazosin), did not inhibit the efflux of DEA (Fig. 1), indicating that an $\mathrm{ABC}$ transporter, which is different from these transporters, plays a role in the efflux of DEA in A549 cells. $\mathrm{T}_{3}$, which exhibited an inhibitory effect on DEA efflux in Caco-2 cells, did not affect the accumulation of DEA in A549 cells (Fig. 1). On the other hand, $100 \mu \mathrm{M}$ AMD caused an approximately $200 \%$ increase in DEA content in A549 cells, although AMD accumulation was not affected by $100 \mu \mathrm{M}$ DEA (Table 1). This increase in intracellular DEA accumulation by AMD might cause the higher accumulation of DEA in lung tissue than that of AMD, since AMD concentration around the alveolar epithelium is presumed to be very high under long-term AMD therapy.

Table 1. Effects of Various Compounds on the Accumulation of AMD (A) or DEA (B) in A549 Cells

(A)

\begin{tabular}{ccc}
\hline \hline Compound & Concentration & AMD accumulation \\
\hline & $\mu \mathrm{M}$ & $\%$ of control \\
FCCP & 50 & $101 \pm 5$ \\
CCCP & 50 & $94.5 \pm 4.2$ \\
DNP & 100 & $104 \pm 6$ \\
DEA & 100 & $111 \pm 12$ \\
\hline
\end{tabular}

(B)

\begin{tabular}{ccc}
\hline \hline Compound & Concentration & DEA accumulation \\
\hline & $\mu_{\mathrm{M}}$ & $\%$ of control \\
FCCP & 50 & $129 \pm 15^{*}$ \\
CCCP & 50 & $127 \pm 7^{* *}$ \\
DNP & 100 & $134 \pm 12^{* *}$ \\
AMD & 100 & $218 \pm 27^{* *}$
\end{tabular}

A549 cells were incubated with AMD $(25 \mu \mathrm{M})($ A) or DEA $(25 \mu \mathrm{M})(\mathrm{B})$ for $60 \mathrm{~min}$ at pH 5.0 at $37^{\circ} \mathrm{C}$. Each value represents the mean \pm S.D. of 3 measurements. $*$ Significantly different from control at $p<0.05$. ** Significantly different from control at $p<0.01$. 
Effect of AMD on ATP Content in A549 Cells Since it has been reported that ATP levels in hamster lung alveolar macrophages, alveolar type II cells and nonciliated bronchiolar epithelial cells were significantly decreased at 4 to $6 \mathrm{~h}$ by $100 \mu \mathrm{M}$ AMD prior to lung cell death, ${ }^{18)}$ it is possible that the increase in DEA accumulation by AMD in A549 cells was mediated by an ATP-dependent DEA efflux mechanism. Thus, we investigated ATP levels in A549 cells exposed to AMD or FCCP at 1 to $3 \mathrm{~h}$. With $1 \mathrm{~h}$ of incubation, the cellular ATP level was reduced slightly by $100 \mu \mathrm{M}$ AMD or $50 \mu \mathrm{M}$ FCCP. With $2 \mathrm{~h}$ and $3 \mathrm{~h}$ of incubation, AMD and FCCP caused an approximately $20 \%$ decrease in cellular ATP content (Fig. 2). Although the reducing effect of AMD on cellular ATP levels and that of FCCP were similar, the enhancing effect of AMD on DEA accumulation was stronger than that of FCCP (Table 1B). Thus, the mechanism of increase in DEA accumulation by AMD might be different from the

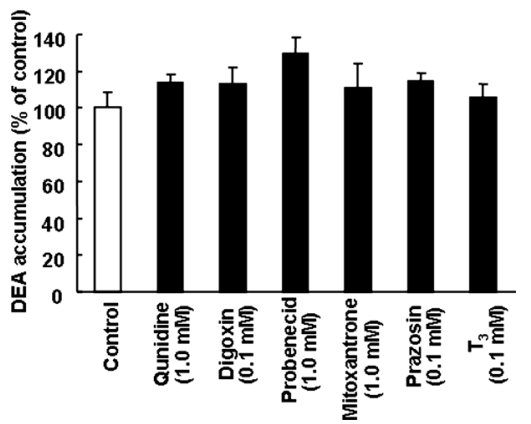

Fig. 1. Effects of Various $A B C$ Transporter Substrates and $T_{3}$ on Accumulation of DEA in A549 Cells

A549 cells were incubated with DEA $(25 \mu \mathrm{M})$ for $60 \mathrm{~min}$ at $\mathrm{pH} 5.0$ at $37^{\circ} \mathrm{C}$. Each column represents the mean with S.D. of 3 measurements.

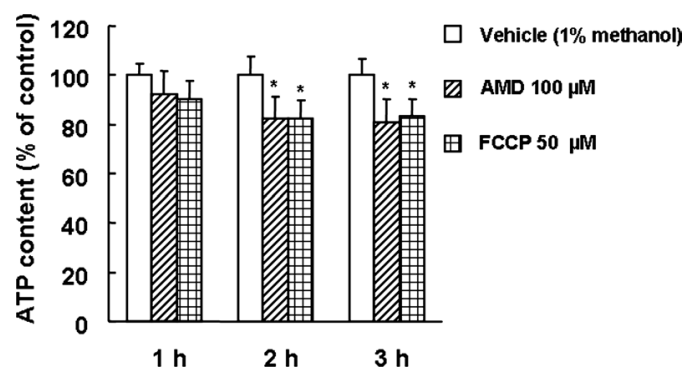

Fig. 2. Effects of $100 \mu \mathrm{M}$ AMD and $50 \mu \mathrm{M}$ FCCP on ATP Content in A549 Cells

Each column represents the mean with S.D. of 3-4 measurements. * Significantly different from control at $p<0.05$.

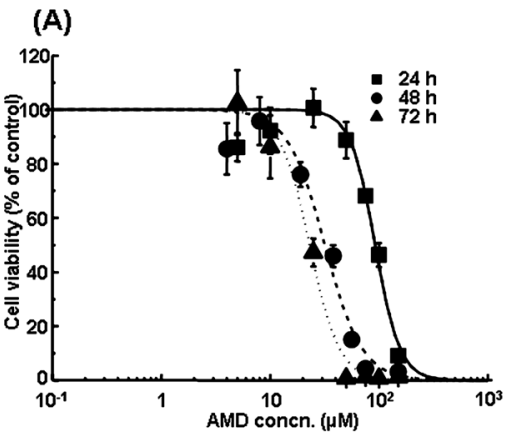

ATP-dependent DEA efflux mechanism. However, this mechanism has not yet been elucidated at the molecular level. Further studies are required to clarify this mechanism and to determine the interaction between DEA and other drugs through this mechanism.

Effects of AMD and DEA on Viability of A549 Cells We examined the effects of AMD and DEA on viability of A549 cells. AMD caused a concentration-dependent loss of cell viability with an $\mathrm{IC}_{50}$ value of $50.1 \pm 4.5 \mu \mathrm{M}$ for $\mathrm{A} 549$ cell viability at $24 \mathrm{~h}$. AMD cytotoxicity was time-dependent until at least $72 \mathrm{~h}$ (Fig. 3A). On the other hand, DEA caused a rapid decrease in cell viability compared to AMD (Fig. $3 \mathrm{~B})$, and this is consistent with previous reports. ${ }^{18)} \mathrm{DEA}$ cytotoxicity reached an almost steady state at $12 \mathrm{~h}$ with an $\mathrm{IC}_{50}$ value of $12.2 \pm 1.0 \mu \mathrm{M}$ and was not enhanced at $18 \mathrm{~h}\left(\mathrm{IC}_{50}\right.$ value of $12.7 \pm 1.5 \mu \mathrm{M}$, data not shown).

Effect of AMD on Viability of DEA-Treated A549 Cells Next, we investigated the effect of the increase of DEA accumulation by AMD on cell viability. As shown in Fig. 4, the enhancing effect of $100 \mu \mathrm{M}$ AMD on DEA accumulation continued for $3 \mathrm{~h}$. In addition, $100 \mu \mathrm{M}$ AMD had no effect on the viability of A549 cells at $3 \mathrm{~h}$ (Fig. 5). Thus, DEA cytotoxicity in the presence of AMD was evaluated at $3 \mathrm{~h}$ to avoid AMD-induced cytotoxicity. Bargout et al. reported that A549 cells do not express P450 monooxygenase, which plays a role in AMD metabolism, ${ }^{27)}$ and we also confirmed that DEA was not detected in a long-period uptake study of AMD in A549 cells (data not shown). Thus, the increase of cyototoxicity by the metabolism of AMD to DEA could be negligible in A549 cells. The $\mathrm{IC}_{50}$ value of DEA for A549 cell viability was $25.4 \pm 2.4 \mu \mathrm{M}$. However, the decrease in cell viability by

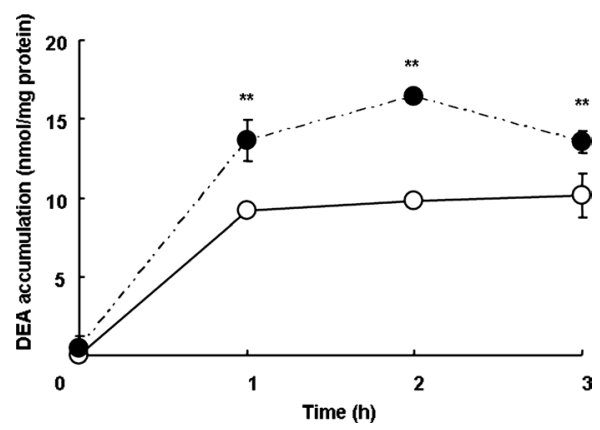

Fig. 4. Effect of AMD on Accumulation of DEA in A549 Cells

A549 cells were incubated with DEA $(10 \mu \mathrm{M})$ at pH 5.0 at $37^{\circ} \mathrm{C}$ in the absence (open circles) or presence (closed circles) of $100 \mu \mathrm{M}$ AMD. Each point represents the mean \pm S.D. of 3 measurements. $* *$ Significantly different from the value measured in the absence of AMD at $p<0.01$.

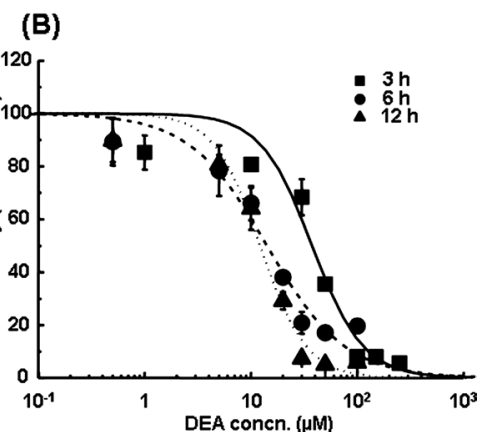

Fig. 3. Effects of AMD (A) and DEA (B) on Viability of A549 Cells Cell viability was assessed by the MTT assay. Each point represents the mean \pm S.D. of $5-6$ measurements. 


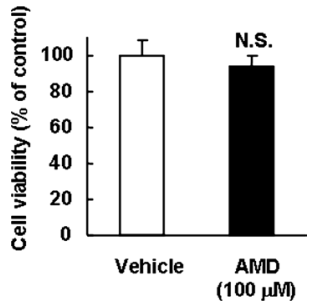

Fig. 5. Effect of AMD on Viability A549 Cells at Early Times

A549 cells were treated with vehicle ( $1 \%$ methanol) or $100 \mu \mathrm{M}$ AMD for $3 \mathrm{~h}$. Cell viability was assessed by the MTT assay. Each column represents the mean with S.D. of 5-6 measurements. N.S.; not significant.

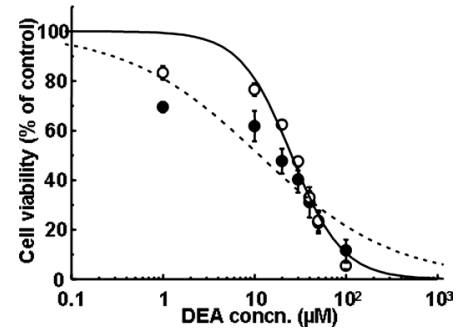

Fig. 6. Effect of AMD on $\mathrm{IC}_{50}$ Value of DEA for A549 Cell Viability

A549 cells were treated with various concentrations of DEA for $3 \mathrm{~h}$ in the absence (open circles) or presence (closed circles) of $100 \mu \mathrm{M}$ AMD Cell viability was assessed by the MTT assay. Each point represents the mean \pm S.D. of 5-6 measurements.

DEA in the presence of AMD was more pronounced than that by DEA alone, with an $\mathrm{IC}_{50}$ value of $11.5 \pm 3.0 \mu \mathrm{M}$ (Fig. $6)$, which is close to the therapeutic serum level of DEA $(2.06 \pm 1.08 \mu \mathrm{M})$ using a mean oral daily maintenance dosage of AMD $(440 \pm 253 \mathrm{mg} / \mathrm{d}){ }^{28)}$ Thus, it is possible that further DEA accumulation by AMD leads to an increase in the incidence of AIPT.

In this study, to clarify the cause of high accumulation of DEA in the lung, we characterized the mechanism of DEA accumulation using A549 cells as a model of the alveolar epithelium. DEA accumulation was increased under a ATPdepleted condition in A549 cells as demonstrated in our previous study in Caco-2 cells. However, $\mathrm{T}_{3}$ did not affect the accumulation of DEA, indicating that ATP-dependent DEA efflux and the effect of $\mathrm{T}_{3}$ on DEA accumulation might be mediated by different mechanisms. On the other hand, DEA accumulation was significantly increased by AMD, and DEA cytotoxcity was enhanced in the presence of AMD. The results suggest that the mechanism of increase in DEA accumulation by AMD is different from the ATP-dependent DEA efflux mechanism. The mechanism of DEA accumulation by AMD may explain the higher tendency of DEA than that of AMD to accumulate in the lung.

Acknowledgement This work was supported in part by a grant from The Research Foundation for Pharmaceutical
Sciences.

\section{REFERENCES}

1) Herre J. M., Sauve M. J., Malone P., Griffin J. C., Helmy I., Langberg J. J., Goldberg H., Scheinman M. M., J. Am. Coll. Cardiol., 13, 442449 (1989).

2) Ceremuzynski L., Kleczar E., Krzeminska-Pakula M., Kuch J., Nartowicz E., Smielak-Korombel J., Dyduszynski A., Maciejewicz J., Zaleska T., Lazarczyk-Kedzia E., Motyka J., Paczkowska B., Sczaniecka O., Yusuf S., J. Am. Coll. Cardiol., 20, 1056-1062 (1992).

3) Hondeghem L. M., Snyders D. J., Circulation, 81, 686-690 (1990).

4) Connolly S. J., Circulation, 100, 2025-2034 (1999).

5) Marchlinski F. E., Gansler T. S., Waxman H. L., Josephson M. E., Ann. Intern. Med., 97, 839-845 (1982).

6) Martin W. J., Rosenow E. C., Chest, 93, 1067-1075 (1988).

7) Pitcher W. D., Am. J. Med. Sci., 303, 206-212 (1992).

8) Sunderji R., Kanji Z., Gin K., Can. J. Cardiol., 16, 1435-1440 (2000).

9) Ohyama K., Nakajima M., Suzuki M., Shimada N., Yamazaki H., Yokoi T., Br. J. Clin. Pharmacol., 49, 244-253 (2000).

10) Ohyama K., Nakajima M., Nakamura S., Shimada N., Yamazaki H., Yokoi T., Drug Metab. Dispos., 28, 1303-1310 (2000).

11) Fabre G., Julian B., Saint-Aubert B., Joyeux H., Berger Y., Drug Metab. Dispos., 21, 978-985 (1993).

12) Katoh M., Nakajima M., Yamazaki H., Yokoi T., Eur. J. Pharm. Sci., 12, 505-513 (2001)

13) Heger J. J., Prystowsky E. N., Zipes D. P., Am. Heart J., 106, 931—935 (1983).

14) Marchiset D., Bruno R., Djiane P., Cano J. P., Benichou M., Serradimigni A., Biopharm. Drug Dispos., 6, 209-215 (1985).

15) Stäubli M., Troendle A., Schmid B., Balmer P., Kohler B., Studer H., Bircher J., Eur. J. Clin. Pharmacol., 29, 417-423 (1985).

16) Blake T. L., Reasor M. J., Inflammation, 19, 55-65 (1995).

17) Massey T. E., Leeder R. G., Rafeiro E., Brien J. F., Can. J. Physiol. Pharmacol., 73, 1675-1685 (1995).

18) Bolt M. W., Card J. W., Racz W. J., Brien J. F., Massey T. E., J. Pharmacol. Exp. Ther., 298, 1280-1289 (2001).

19) Vereckei A., Blazovics A., Gyorgy I., Feher E., Toth M., Szenasi G., Zsinka A., Foldiak G., Feher J., J. Cardiovasc. Electrophysiol., 4, 161-177 (1993)

20) Daniels J. M., Brien J. F., Massey T. E., Toxicol. Appl. Pharmacol., 100, 350-359 (1989).

21) Adams P. C., Holt D. W., Storey G. C., Morley A. R., Callaghan J., Campbell R. W., Circulation, 72, 1064-1075 (1985).

22) Ruch R. J., Bandyopadhyay S., Somani P., Klaunig J. E., Toxicol. Lett., 56, 117-126 (1991).

23) Kakumoto M., Takara K., Sakaeda T., Tanigawara Y., Kita T., Okumura K., Biol. Pharm. Bull., 25, $1604-1607$ (2002).

24) Kimoto E., Seki S., Itagaki S., Matsuura M., Kobayashi M., Hirano T., Goto Y., Tadano K., Iseki K., Drug Metab. Pharmacokinet., 22, 307312 (2007).

25) Mosmann T., J. Immunol. Methods, 65, 55-63 (1983).

26) Lowry O. H., Rosebrough N. J., Farr A. L., Randall R. J., J. Biol. Chem., 193, 265-275 (1951).

27) Bargout R., Jankov A., Dincer E., Wang R., Komodromos T., IbarraSunga O., Filippatos G., Uhal B. D., Am. J. Physiol. Lung Cell Mol. Physiol., 278, 1039-1044 (2000).

28) Plomp T. A., van Rossum J. M., Robles de Medina E. O., van Lier T., Maes R. A., Arzneim.-Forsch., 34, 513-520 (1984). 